\title{
Combined effects of inorganic carbon and light on Phaeocystis globosa Scherffel (Prymnesiophyceae)
}

\author{
A. Hoogstraten ${ }^{1}$, M. Peters ${ }^{1}$, K. R. Timmermans ${ }^{1}$, and H. J. W. de Baar ${ }^{1,2}$ \\ ${ }^{1}$ Royal Netherlands Institute for Sea Research (NIOZ), Department of Biological Oceanography, P.O. Box 59, \\ 1790 AB Den Burg, The Netherlands \\ ${ }^{2}$ University of Groningen, Department of Ocean Ecosystems, Nijenborg 7, 9747 AG Groningen, The Netherlands
}

Correspondence to: A. Hoogstraten (astrid.hoogstraten@nioz.nl)

Received: 2 December 2011 - Published in Biogeosciences Discuss.: 21 December 2011

Revised: 30 April 2012 - Accepted: 2 May 2012 - Published: 29 May 2012

\begin{abstract}
Phaeocystis globosa (Prymnesiophyceae) is an ecologically dominating phytoplankton species in many areas around the world. It plays an important role in both the global sulfur and carbon cycles, by the production of dimethylsulfide (DMS) and the drawdown of inorganic carbon. Phaeocystis globosa has a polymorphic life cycle and is considered to be a harmful algal bloom (HAB) forming species. All these aspects make this an interesting species to study the effects of increasing carbon dioxide $\left(\mathrm{CO}_{2}\right)$ concentrations, due to anthropogenic carbon emissions.

Here, the combined effects of three different dissolved carbon dioxide concentrations $\left(\mathrm{CO}_{2(\mathrm{aq})}\right)$ (low: $4 \mu \mathrm{mol} \mathrm{kg}{ }^{-1}$, intermediate: $6-10 \mu \mathrm{mol} \mathrm{kg}^{-1}$ and high $\mathrm{CO}_{2(\mathrm{aq})}$ : 21$24 \mu \mathrm{mol} \mathrm{kg}{ }^{-1}$ ) and two different light intensities (low light, suboptimal: $80 \mu \mathrm{mol}$ photons $\mathrm{m}^{-2} \mathrm{~s}^{-1}$ and high light, light saturated: $240 \mu \mathrm{mol}$ photons $\mathrm{m}^{-2} \mathrm{~s}^{-1}$ ) are reported.

The experiments demonstrated that the specific growth rate of $P$. globosa in the high light cultures decreased with increasing $\mathrm{CO}_{2(\mathrm{aq})}$ from 1.4 to $1.1 \mathrm{~d}^{-1}$ in the low and high $\mathrm{CO}_{2}$ cultures, respectively. Concurrently, the photosynthetic efficiency $\left(F_{\mathrm{V}} / F_{\mathrm{M}}\right)$ increased with increasing $\mathrm{CO}_{2(\mathrm{aq})}$ from 0.56 to 0.66 . The different light conditions affected photosynthetic efficiency and cellular chlorophyll $a$ concentrations, both of which were lower in the high light cultures as compared to the low light cultures. These results suggest that in future inorganic carbon enriched oceans, $P$. globosa will become less competitive and feedback mechanisms to global change may decrease in strength.
\end{abstract}

\section{Introduction}

The genus of Phaeocystis (Prymnesiophyceae) has a global distribution and consists of several species, three of which are known to form large blooms of colonies ( $P$. antarctica, $P$. pouchetii and $P$. globosa). While the first two species are found in Antarctic and Arctic waters respectively, P. globosa is found in temperate and tropical waters (Schoemann et al., 2005). Like the other two species, P. globosa is well known for its polymorphic life cycle, during which it alternately occurs as 4 different morphotypes; diploid colonial cells, diploid flagellates and two different types of haploid flagellates (Rousseau et al., 2007). Solitary cells of P. globosa can be grazed upon by micro-zooplankton and are susceptible to viral infection. The large colonies on the other hand, which can reach a size of up to $3 \mathrm{~cm}$ in diameter and can contain thousands of cells in a polysaccharide matrix, are grazed upon by meso-zooplankton, and are not prone to viral infection (Schoemann et al., 2005; Whipple et al., 2005 and references therein). It is not exactly clear what causes colony formation in P. globosa. Colonies are always preceded by solitary cells (Whipple et al., 2005). One of the triggers for colony formation in the Dutch coastal zone of the North Sea appears to be light, where colony formation starts when a daily irradiance threshold of $100 \mathrm{~W} \mathrm{~m}^{-2} \mathrm{~d}^{-1}$, assuming a $12 \mathrm{~h}$ light period, is reached. This is comparable to approximately $40 \mu \mathrm{mol}$ photons $\mathrm{m}^{-2} \mathrm{~s}^{-1}$ (Peperzak et al., 1998; L. Peperzak, NIOZ, Texel, personal communication, 2012). However, this irradiance threshold is strain dependent, since colony formation of other strains has been observed in light conditions between 10 and $20 \mu \mathrm{mol}$ photons $\mathrm{m}^{-2} \mathrm{~s}^{-1}$ 
(Riegman and van Boekel, 1996 and references therein). Other possible triggers for colony formation are grazing, grazer-released info chemicals, genetic mechanisms, nutrient conditions, the presence of substrate and water turbulence (Whipple et al., 2005; Rousseau et al., 1994, 2007 and references therein). The presence of grazers increases the colony size of P. globosa (Tang, 2003). In the Dutch coastal North Sea and the Wadden Sea, blooms of P. globosa occur annually (April-June). Here, these blooms are a cause of nuisance when the organic foam, which is formed due to partial degradation of the colonies, is blown on the beaches, thereby having negative impacts on tourism (Peperzak, 2003; Schoemann et al., 2005). Furthermore, blooms of $P$. globosa have been found to be responsible for mass mortality of caged fish in China in 1997 (Lu and Huang, 1999; Chen et al., 2002) and of shellfish (mussels) in the Oosterschelde estuary in 2001 (Peperzak and Poelman, 2008). These events of mass mortality are most likely due to the bacterial degradation of the large amounts of organic matter formed during a bloom, which can lead to local hypoxia and increased concentrations of sulfide and ammonia (Peperzak and Poelman, 2008). Therefore, this species is generally classified as a harmful algal bloom (HAB) species. Besides being recognized as a harmful species, Phaeocystis globosa is also known for the production of dimethylsulfoniopropionate (DMSP). After release from the cell, part of the DMSP is enzymatically cleaved into dimethylsulfide (DMS) and acrylate (Stefels et al., 1995; Stefels, 2000). The DMS production by P. globosa in the Dutch coastal North Sea is largest during the start of the exponential growth phase of the bloom. However, this appears to be strain specific. In Chinese waters, DMSP production by $P$. globosa is higher in the stationary phase than in the exponential phase. Here, DMSP production and DMS release is strongly affected by the temperature and the salinity of the seawater (Shen et al., 2011). While the exact function of DMSP for the algal cell is still unknown, it is known that it serves as osmotic protection. Furthermore, in the atmosphere, the oxidation products of DMS can impact global climate by acting as condensation nuclei, changing the cloud albedo, and having a cooling effect on Earth's climate (Charlson et al., 1987; Stefels et al., 1995; Stefels, 2000; Clarke et al., 1998). This gives P. globosa an important role in the Earth's sulfur cycle (Schoemann et al., 2005).

The decline of a Phaeocystis bloom is usually characterized by two phenomena: the formation of micro-aggregates through the invasion of the mucus by bacteria; and the formation of ghost colonies, which are due to the emigration of flagellated cells from the colony into the external medium. These flagellated cells can induce a new bloom (Rousseau et al., 1994). Although colonies are not susceptible to viral infection, solitary cells are, and therefore, viral lysis is an important actor in carbon recycling. It is a major loss factor for P. globosa and other Phaeocystis species and can terminate a bloom in a relatively short time span, thereby providing other microbes with substantial amounts of organic carbon (Brussaard et al., 2005; Jacobsen et al., 2007). Most of the assimilated carbon is recycled in the surface waters through the microbial food web and never reaches deeper waters (Schoemann et al., 2005). The sequestration of inorganic carbon in subsurface waters by P. globosa is influenced by the environmental conditions under which a bloom develops (Mari et al., 2005). Carbon sequestration by P. globosa is reduced when the bloom develops under nitrogen limitation, as compared to phosphorus limitation (Mari et al., 2005). It is therefore important to consider the effects of nutrient conditions for predictions of bloom development, especially when predicting bloom development in future oceans. The large blooms of $P$. globosa assimilate significant amounts of inorganic carbon into cell material and mucus and may therefore act as a feedback mechanism to increasing carbon concentrations in the atmosphere. Measurements have shown that the surface water $p \mathrm{CO}_{2}$ of the Wadden Sea was reduced to on average $270 \mu$ atm during April and May 2009, the spring bloom period, compared to an atmospheric concentration of approximately $380 \mu \mathrm{atm}$ (L. Salt, NIOZ, Texel, personal communication, 2011).

Atmospheric carbon dioxide $\left(\mathrm{CO}_{2}\right)$ concentrations are increasing due to anthropogenic carbon dioxide $\left(\mathrm{CO}_{2}\right)$ emissions. According to current predictions, following the A1B scenario of the Intergovernmental Panel on Climate Change (IPCC), this rise will continue and atmospheric $\mathrm{CO}_{2}$ concentrations will increase up to $800 \mu \mathrm{atm}$ by the year $2100 \mathrm{AD}$ (Meehl et al., 2007). As $\mathrm{CO}_{2}$ is a greenhouse gas and can absorb infrared (IR) energy (Millero, 1996), this rise can lead to a surface temperature increase of $2.8^{\circ} \mathrm{C}$ by $2100 \mathrm{AD}$ according to this same scenario. Further important effects of this increase in atmospheric $\mathrm{CO}_{2}$ concentration are increased stratification at higher latitude surface waters due to a decrease in the strength of the Meridional Overturning Circulation (MOC), and a decrease in cloud cover and precipitation in the low and mid-latitudes, whereas cloud cover and precipitation in the high latitudes will increase (Meehl et al., 2007). The combination of increased stratification and decreased cloud cover will cause phytoplankton to encounter longer periods of high light conditions. Furthermore, by the continuous exchange of $\mathrm{CO}_{2}$ between the atmosphere and surface waters, a large part of the anthropogenic $\mathrm{CO}_{2}$ is stored in the oceans, thereby increasing the $\mathrm{CO}_{2}$ concentrations in the surface waters (Sabine et al., 2004). This changes the carbonate chemistry of these waters, leading to an increase in aqueous carbon dioxide $\left(\mathrm{CO}_{2(\mathrm{aq})}\right)$ and bicarbonate ion $\left(\mathrm{HCO}_{3}^{-}\right)$concentrations, but a decrease in carbonate ion $\left(\mathrm{CO}_{3}^{2-}\right)$ concentrations (Millero, 1996). It is likely that these changes in the carbon chemistry will affect marine primary producers. To date, only few of the marine primary producers have been studied and the focus has been mainly on calcifying organisms, such as Emiliania huxleyi (Engel et al., 2005; Iglesias-Rodriguez et al., 2008), and diatoms, such as the temperate HAB species Pseudonitzschia multiseries (Sun 
et al., 2011) and the Southern Ocean diatom species Proboscia alata (Hoogstraten et al., 2012). Studies on the effects of different $\mathrm{CO}_{2}$ concentrations on $\mathrm{HAB}$ species have been done, notably on dinoflagellates, such as Karlodinium veneficum (Fu et al., 2010), and diatoms; in example different Pseudonitzschia species (Sun et al., 2011; Tatters et al., 2012). Results of these studies show that toxicity of these species increases with increasing $\mathrm{CO}_{2}$ concentrations, especially in the case of a combined effect of nutrient limitation and high $\mathrm{CO}_{2}$. For Phaeocystis globosa a number of studies have been published on the effects of temperature increase, $\mathrm{CO}_{2}$ increase and different light regimes on the species. A study by Peperzak (2003) has shown that due to temperature increase, as an accompanying anthropogenic effect, blooms of $P$. globosa will most likely decrease. Similarly, a more recent study by Wang et al. (2010b) showed a decrease in colony size with increasing temperature. In a different study Wang et al. (2010a) focused on inorganic carbon effects, but did not include temperature or light, and showed that the colonial biomass of $P$. globosa will increase, while the biomass of solitary cells will decrease in the tested future high $\mathrm{CO}_{2}$ scenario of $750 \mu \mathrm{atm}$. Chen and Gao (2011) found that there is a combined effect of light, UV-radiation and $\mathrm{CO}_{2}$ concentration on the photosynthetic yield and growth rate. Because the focus of this study was towards photosynthesis and growth, many other parameters, such as nutrient uptake rates and organic carbon production, have not been described in this latter study. Here we report on the results of a study on the combined effects of both inorganic carbon concentration and light intensity on P. globosa and give insight in possible future changes in the abundance of this species in the Dutch coastal North Sea and Wadden Sea. Solitary cells of $P$. globosa were cultured semi-continuously in two different light intensities, which were chosen to be suboptimal (referred to as low light: LL $80 \mu \mathrm{mol}$ photons $\mathrm{m}^{-2} \mathrm{~s}^{-1}$ ) and saturating (referred to as high light, HL: $240 \mu \mathrm{mol}$ photons $\mathrm{m}^{-2}$ $\mathrm{s}^{-1}$ ) light intensity for cell division (Jahnke, 1989). Three different dissolved carbon dioxide $\left(\mathrm{CO}_{2(\mathrm{aq})}\right)$ concentrations (respectively, 4, 10 and $21 \mu \mathrm{mol} \mathrm{kg}{ }^{-1}$ for low, intermediate and high $\mathrm{CO}_{2(\mathrm{aq})}$ in the high light cultures, and 4, 6 and $24 \mu \mathrm{mol} \mathrm{kg}{ }^{-1}$ for low, intermediate and high $\mathrm{CO}_{2(\mathrm{aq})}$ in the low light cultures) were used. These concentrations correspond to a $p \mathrm{CO}_{2}$ range of 100 to $600 \mu \mathrm{atm}$, spanning a range of glacial $p \mathrm{CO}_{2}$ under bloom conditions, to the predicted concentration in 50-60 yr from now (Meehl et al., 2007).

\section{Materials and methods}

\subsection{Experimental setup}

Prior to the experiments, a solitary cell strain of Phaeocystis globosa (strain Pg G(A)) originating from the North Sea (T135, Terschelling, $135 \mathrm{~km}$ off the coast, isolated by R. Koeman in 2000) was cultured in aged natural seawater originating from the Gulf of Biscay in 1998 (as described by Timmermans et al., 2001). This natural seawater was filtered upon collection and kept in the dark in $1 \mathrm{~m}^{3}$ vessels. The seawater was filter sterilized with a Sartobran 105 filter (pre-filter $0.45 \mu \mathrm{m}$ and end-filter $0.20 \mu \mathrm{m}$ pore size). Because this seawater has very low nutrient concentrations (nitrate: $0.04 \mu \mathrm{mol}^{-1}$, phosphate $0.03 \mu \mathrm{mol} 1^{-1}$ and silicate $0.84 \mu \mathrm{mol}^{-1}$ ), major nutrients were added to a final concentration of $60 \mu \mathrm{mol} \mathrm{l} 1^{-1} \mathrm{NO}_{3}^{-}, 3.75 \mu \mathrm{mol} \mathrm{l} \mathrm{l}^{-1} \mathrm{PO}_{4}^{3-}$ and $60 \mu \mathrm{mol} 1^{-1} \mathrm{Si}(\mathrm{OH})_{4}$. The stock culture of P. globosa was regularly diluted in order to keep the cells in exponential growth prior to the experiment.

The experimental setup consists of 61 polymethylmethacrylate (PMMA) culture vessels. These were water jacketed and temperature controlled with thermostat baths (Lauda Ecoline StarEdition RE104), set to $15.0^{\circ} \mathrm{C}( \pm 0.1)$, to ensure constant temperature in the culture vessels. The PMMA has a negligible gas diffusion coefficient for $\mathrm{CO}_{2}$ and is transparent for the photosynthetic active radiation (PAR) spectrum. The tubing and ports in the lid of the culture vessels (sampling, addition of medium, and the air in- and outlet) were made of PFA tubing (Teflon, Polyfluor Plastics, The Netherlands) and nylon (Swagelok, USA), respectively, to ensure gas tight connections. The gas supply and outlet had filters attached in order to prevent particles present in the air to reach the culture vessels. Light conditions in the culture vessels were saturating light (high light intensity or HL: $240 \mu \mathrm{mol}$ photons $\mathrm{m}^{-2} \mathrm{~s}^{-1}$ ) or suboptimal light (low light intensity or LL: $80 \mu \mathrm{mol}$ photons $\mathrm{m}^{-2} \mathrm{~s}^{-1}$ ) in a $16: 8 \mathrm{~h}$ light:dark cycle. Light was provided by Biolux cool daylight lamps (Philips, TL-D 965/18W). The culture vessels were filled with 51 medium and 11 air and were continuously aerated with recycled air from the medium supply vessels, thus reducing the amount of $\mathrm{CO}_{2}$ enriched gas needed for the aeration. Three different natural air mixtures (atmospheric air, with adjusted $\mathrm{CO}_{2}$ concentration, HiQ-Line Linde gas Benelux, Schiedam, The Netherlands) were used for the experiments: $190 \mu \mathrm{atm}, 380 \mu \mathrm{atm}$ and $750 \mu \mathrm{atm} \mathrm{CO}_{2}$. The aeration resulted in three different $\mathrm{CO}_{2(\mathrm{aq})}$ concentrations for each light condition (Table 1). A Teflon coated stirrer bar connected to the lid of the culture vessel by a flexible joint, ensured continuous gently stirring of the culture at a speed of $50 \mathrm{rpm}$. Prior to the experiments, P. globosa was grown in the experimental setup as a batch culture for 8 days in order to determine the different growth phases (lag phase, exponential phase and the senescent phase, Fig. 1a). After this, the cultures were diluted to low cell abundance, which was determined as described below, (early in the exponential growth phase: $1.5 \times 10^{4}$ cells ml $^{-1}$ ) and cultured semicontinuously for 6 days (pre-experimental phase, cell abundance ranging between $1.3 \times 10^{4}$ and $5.6 \times 10^{4}$ cells ml $^{-1}$, $\sim 8$ generations, Fig. 1b), during which the total culture volume was exchanged three times, in order to realize and maintain a stable environment and allowing the cells to adapt to 
Table 1. Average ( \pm standard deviation) concentrations of total alkalinity $\left(A_{\mathrm{T}}, n=12\right)$ and dissolved inorganic carbon (DIC), both in $\mu \mathrm{mol} \mathrm{kg}-1$ and $p \mathrm{CO}_{2}(\mu \mathrm{atm})$ and $\mathrm{CO}_{2(\mathrm{aq})}\left(\mu \mathrm{mol} \mathrm{kg}{ }^{-1}\right)$, in the culture vessels with $P$. globosa. Based on the measured $A_{\mathrm{T}}$ and DIC concentrations (data in Supplement, Tables S2 and S3), the $p \mathrm{CO}_{2}$ ( $\mu$ atm) and $\mathrm{CO}_{2(\mathrm{aq})}\left(\mu \mathrm{mol} \mathrm{kg}{ }^{-1}\right.$ ) were calculated (see Sect. 2). The average $\mathrm{CO}_{2(\mathrm{aq})}$ concentration $\left(\mu \mathrm{mol} \mathrm{kg} \mathrm{k}^{-1}\right.$ ) in the supply vessel was based on the measured $\mathrm{A}_{\mathrm{T}}$ and DIC concentration in the supply vessels.

$$
\begin{array}{llllll}
\begin{array}{l}
A_{\mathrm{T}} \text { measured } \\
\left.(\mu \mathrm{mol} \mathrm{kg})^{-1}\right)
\end{array} & \begin{array}{l}
A_{\mathrm{T} \text { predicted }} \\
\left(\mu \mathrm{mol} \mathrm{kg}{ }^{-1}\right)
\end{array} & \begin{array}{l}
\mathrm{DIC} \\
\left.(\mu \mathrm{mol} \mathrm{kg})^{-1}\right)
\end{array} & p \mathrm{CO}_{2}(\mu \mathrm{atm}) & \begin{array}{l}
\mathrm{CO}_{2(\mathrm{aq})} \\
\left(\mu \mathrm{mol} \mathrm{kg}^{-1}\right)
\end{array} & \begin{array}{l}
\text { Supply } \\
\text { vessel } \mathrm{CO}_{2(\mathrm{aq})} \\
\left(\mu \mathrm{mol} \mathrm{kg}{ }^{-1}, n=2\right)
\end{array}
\end{array}
$$

\begin{tabular}{|c|c|c|c|c|c|c|}
\hline \multicolumn{7}{|l|}{ High Light } \\
\hline Low $\mathrm{CO}_{2(\mathrm{aq})}(n=11)$ & $2476.3( \pm 3.9)$ & $2480.7( \pm 1.8)$ & $1921.7( \pm 15.7)$ & $109.6( \pm 6.8)$ & $4.1( \pm 0.3)$ & $5.0( \pm 0.2)$ \\
\hline Intermediate $\mathrm{CO}_{2(\mathrm{aq})}(n=10)$ & $2476.2( \pm 3.9)$ & $2487.2( \pm 1.8)$ & $2130.9( \pm 15.7)$ & $259.0( \pm 6.8)$ & $9.7( \pm 0.3)$ & $12.2( \pm 0.2)$ \\
\hline $\operatorname{High} \mathrm{CO}_{2(\mathrm{aq})}(n=11)$ & $2477.1( \pm 5.8)$ & $2492.4( \pm 1.4)$ & $2284.1( \pm 19.1)$ & $549.4( \pm 52.1)$ & $20.5( \pm 1.9)$ & $23.1( \pm 0.7)$ \\
\hline \multicolumn{7}{|l|}{ Low Light } \\
\hline Low $\mathrm{CO}_{2(\mathrm{aq})}(n=11)$ & $2475.8( \pm 3.9)$ & $2477.7( \pm 1.3)$ & $1939.9( \pm 19.4)$ & $117.9( \pm 8.2)$ & $4.2( \pm 0.3)$ & $5.1(n=1)$ \\
\hline Intermediate $\mathrm{CO}_{2(\mathrm{aq})}(n=12)$ & $2474.4( \pm 2.6)$ & $2477.3( \pm 1.1)$ & $2003.4( \pm 18.5)$ & $152.4( \pm 10.7)$ & $5.7( \pm 0.4)$ & $7.2( \pm 0.0)$ \\
\hline $\operatorname{High~} \mathrm{CO}_{2(\mathrm{aq})}(n=12)$ & $2479.0( \pm 3.0)$ & $2492.0( \pm 1.5)$ & $2313.2( \pm 9.9)$ & $641.8( \pm 37.2)$ & $24.0( \pm 1.4)$ & $24.8( \pm 1.9)$ \\
\hline
\end{tabular}

the experimental conditions (as described by Riebesell et al., 2010). Dilutions were made according to cell abundance.

Following the pre-experimental dilution series, the experimental phase started. Again P. globosa was cultured semicontinuously, with cell abundance ranging between $1.5 \times 10^{4}$ to $5.3 \times 10^{4}$ cells $\mathrm{ml}^{-1}$ between dilutions. The experimental phase lasted for 6 days, $\sim 9$ generations (Fig. 1c and d, Supplement Table S1), during which several parameters were measured before and after each dilution: cell abundance, photosynthetic efficiency, inorganic carbon (dissolved inorganic carbon -DIC- and total alkalinity $\left.-A_{\mathrm{T}^{-}}\right)$and dissolved inorganic nutrients (nitrate and phosphate). In addition, before dilution the chlorophyll $a$ concentration, particulate organic carbon (POC) and particulate organic nitrogen (PON) were measured. All samples were taken during the light period of the cultures and at a fixed time every day in the light:dark cycle $(3 \mathrm{~h}$ after onset of the light and $1 \mathrm{~h}$ after dilution in the afternoon).

\subsection{Inorganic carbon}

Following the protocols described by Dickson and Goyet (1994) and Dickson et al. (2007), $250 \mathrm{ml}$ samples were taken from the culture vessels, fixed with $50 \mu \mathrm{l}$ $\mathrm{HgCl}_{2}$, closed and stored in the dark at room temperature. Total alkalinity $\left(A_{\mathrm{T}}\right)$ and total dissolved inorganic carbon (DIC) were determined with a VINDTA 3C (Versatile INstrument for the Determination of Total inorganic carbon and titration Alkalinity, Marianda, Germany). Certified reference materials (CRM, batch \# 100) obtained from Professor A.G. Dickson (Scripps Institution of Oceanography, USA) were included in every series of measurements in order to determine the quality of the data. The sample values were adjusted accordingly. The resulting sample values had a typical accuracy of $5.8 \mu \mathrm{mol} \mathrm{kg}-1$ for both $A_{\mathrm{T}}$ and DIC. From the $A_{\mathrm{T}}$ and DIC the other parameters of the carbonate system ( $\mathrm{pH}$ and $\left.p \mathrm{CO}_{2}\right)$ were calculated as well as the concentration of 3 different carbon species: bicarbonate and carbonate ions and aqueous $\mathrm{CO}_{2}$, by the use of $\mathrm{CO}_{2}$ sys (Lewis and Wallace, 1998). The $\mathrm{CO}_{2}$ dissociation constants of Mehrbach et al. (1973) refitted by Dickson and Millero (1987), the $\mathrm{CO}_{2}$ solubility coefficient of Weiss (1974), the borate acidity constant of Dickson (1990b) and the $\mathrm{SO}_{4}^{2-}$ dissociation constant of Dickson (1990a) were used for the calculations. Salinity, phosphate and silicate concentrations (for the latter the concentration as added to the culture medium, $60 \mu \mathrm{moll}^{-1}$, was used), were incorporated in the calculations.

As mentioned by Kim et al. (2006), particulate organic carbon may have significant effects on the measured $A_{\mathrm{T}}$. Therefore, the measured $A_{\mathrm{T}}$ ( $A_{\mathrm{T} \text { (meas) }}$ ) was compared to the predicted $A_{\mathrm{T}}\left(A_{\mathrm{T}(\mathrm{pred})}\right)$, which was calculated from the $A_{\mathrm{T}}$ of the supply vessels corrected for the nitrate uptake by the phytoplankton (Brewer and Goldman, 1976; Goldman and Brewer, 1980).

\subsection{Cell abundance and specific growth rate}

Cell abundance in the cultures was determined with a Coulter Epics XL·MCL flow cytometer (Beckman Coulter, Inc. Brea CA, USA). All cultures were analyzed in triplicates and average cell abundance was calculated for the determination of the specific growth rate, which was calculated by the linear regression of the natural logarithm of the cell abundance.

\subsection{Photosynthetic parameters}

\subsubsection{Photosynthetic efficiency}

Photosynthetic efficiency $\left(F_{\mathrm{V}} / F_{\mathrm{M}}\right)$ was determined by the analysis of triplicate samples. Prior to the measurements, the samples were left in the dark for at least 5 min to allow for dark adaptation. A PAM fluorometer (Pulse Amplitude 

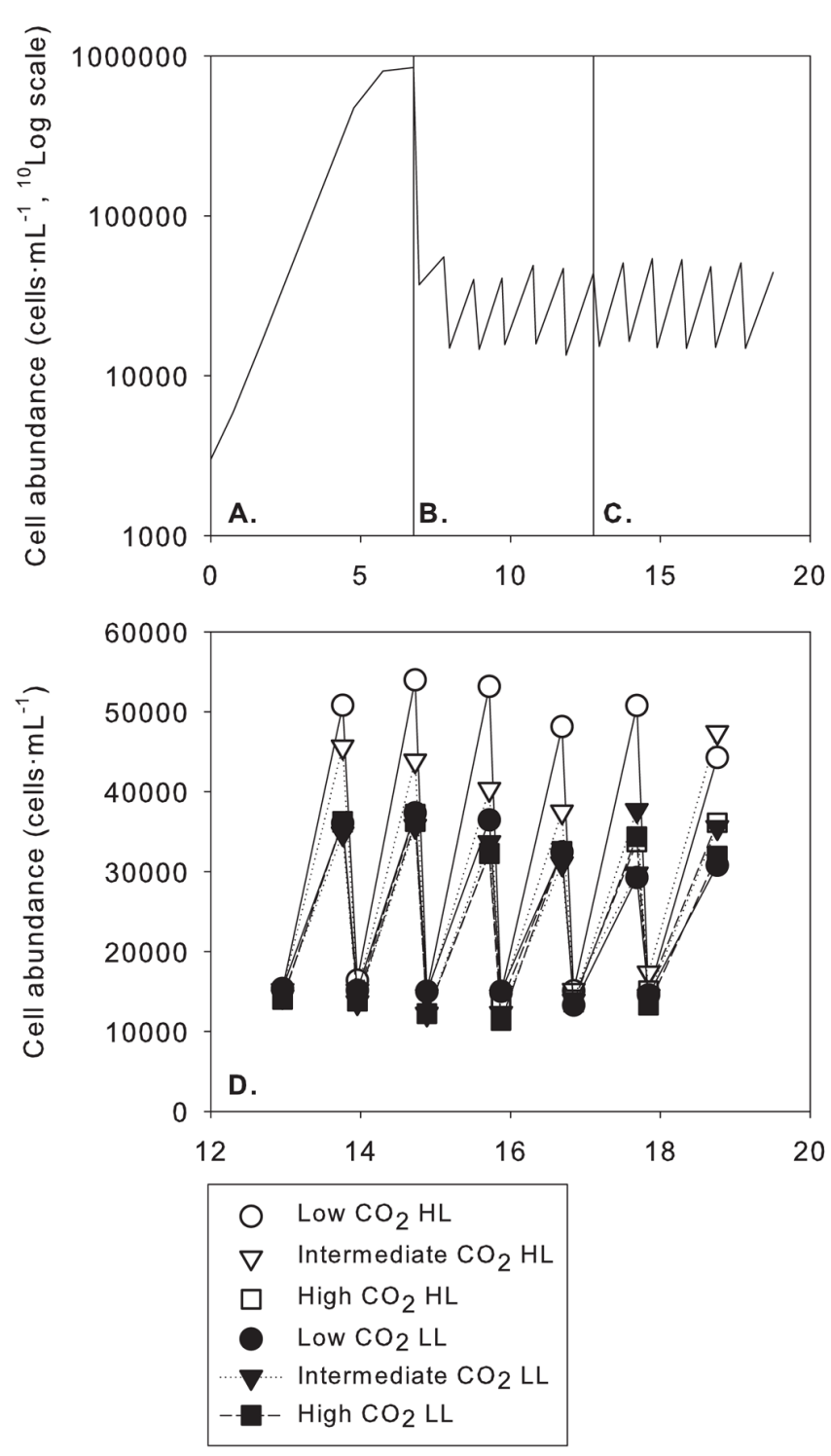

Fig. 1. The typical cell abundance during the different phases of the $\mathrm{CO}_{2(\mathrm{aq})}$ and light manipulation experiments with $P$. globosa, shown for the low $\mathrm{CO}_{2(\mathrm{aq})}$ high light culture in Fig. 1a to c. (A) Batch phase, (B) pre-experimental phase and (C) experimental phase, as described in the Materials and Methods section. (D) Shows the cell abundance during the experimental phase of all treatments. Low and intermediate $\mathrm{CO}_{2(\mathrm{aq})} \mathrm{HL}$ show a faster increase in cell abundance than the other treatments, which are similar to each other. Cell count data can be found in the supplementary files, Table S1. HL denotes high light cultures and LL denotes low light cultures.

Modulated-CONTROL Universal Control Unit, WATERmode, Walz, Germany) was used for the determination of $F_{0}$ (autofluorescence), $F_{\mathrm{M}}$ (maximum fluorescence) and $F_{\mathrm{V}} / F_{\mathrm{M}}$ (photochemical quantum efficiency, where $F_{\mathrm{V}}=F_{\mathrm{M}}-F_{0}$ ).

\subsubsection{Chlorophyll $a$}

Chlorophyll $a$ concentrations of the cultures were determined by filtration of $150 \mathrm{ml}$ sample on a $0.7 \mu \mathrm{m}$ pore size glass fiber filter (GF/F, diameter $25 \mathrm{~mm}$ ). All samples were handled in low light conditions, preventing chlorophyll $a$ degradation. The filters were stored at $-80^{\circ} \mathrm{C}$ until further analysis. Prior to the analysis, chlorophyll $a$ was extracted in $10 \mathrm{ml} 90 \%$ acetone at $-20^{\circ} \mathrm{C}$ for $24 \mathrm{~h}$. Following the protocol designed by Holm-Hansen et al. (1965), the fluorescence of the samples was measured with a SpectraMax M2 spectrofluorometer (with SoftMax Pro software, Molecular Devices) and the chlorophyll $a$ concentration was determined against a chlorophyll $a$ standard solution. The chlorophyll $a$ concentrations were normalized to the cell counts and expressed as pg cell ${ }^{-1}$.

\subsection{Particulate organic carbon and nitrogen}

Particulate organic carbon (POC) and nitrogen (PON) were determined by the filtration of $100 \mathrm{ml}$ sample on a precombusted $0.7 \mu \mathrm{m}$ pore size GF/F filter (diameter $25 \mathrm{~mm}$ ). Filters were stored at $-80^{\circ} \mathrm{C}$ until further analysis. Prior to POC and PON analyses, the filters were freeze dried overnight. The POC and PON samples were analyzed with a Thermo-Interscience Flash EA1112 Series Elemental analyzer, after the protocol of Verardo et al. (1990). The results were corrected for blanks. The POC and PON contents on the filters were normalized to the cell counts and expressed in pmol cell ${ }^{-1}$. For the determination of the POC:Chl $a$ ratio, POC was also calculated as $\mathrm{pg} \mathrm{C} \mathrm{Cell}^{-1}$.

\subsection{Nutrient concentrations}

For the determination of the concentrations of nitrate and phosphate, the samples were filtered over a $0.2 \mu \mathrm{m}$ filter (Acrodisc, $32 \mathrm{~mm}$ syringe filter, Supor membrane, Pall Cooperation, Newquay Cornwall, UK) and stored at $-20^{\circ} \mathrm{C}$ in $6 \mathrm{ml}$ Pony Vials (PerkinElmer Life and Analytical Sciences, Shelton, CT, USA) until further analysis. The vials and syringe were rinsed with MilliQ prior to filtration of the sample. The vials were rinsed 3 times with filtered sample before filling. Analysis of the nutrient samples was done on a TRAACS Auto Analyzer 800+ (Bran + Luebbe, Germany) with the use of spectrophotometric methods, as described by Grasshoff et al. (1983).

Nutrient uptake rates were calculated from the nutrient concentrations before and after the dilution and normalized to cell counts and expressed as fmol cell ${ }^{-1} \mathrm{~d}^{-1}$.

\subsection{Statistical analysis}

All statistical analyses were done with SPSS 17.0 (SPSS Inc., Chicago, IL). Correlation analyses were done when $\left[\mathrm{CO}_{2(\mathrm{aq})}\right]$ was correlated to the different parameters. In order to distinguish between effects caused by light, $\left[\mathrm{CO}_{2(\mathrm{aq})}\right]$ or a 
combination of the two, the data were analyzed with analyses of covariance (ANCOVA, Field, 2007).

\section{Results}

\subsection{Dissolved inorganic carbon and total alkalinity}

Both DIC and $A_{\mathrm{T}}$ (data available in Supplement, Tables S2 and S3) remained constant throughout each of the experiments. The treatments resulted in 3 different $\mathrm{CO}_{2(\mathrm{aq})}$ concentrations for each of the light conditions (Table 1), with less than $10 \%$ variability per light condition throughout the experiments.

A comparison between the measured alkalinity $\left(A_{\mathrm{T} \text { (meas) }}\right)$ and the predicted alkalinity $\left(A_{\mathrm{T} \text { (pred) }}\right)$ showed some discrepancy between the two, with $A_{\mathrm{T}}$ (pred) being slightly higher than $A_{\mathrm{T} \text { (meas) }}$. No correlation between the POC concentration and the difference between the predicted and the measured alkalinity was found $\left(r^{2}=0.03, n=34\right)$ (see Fig. S1 in the Supplement).

When the data of the high light and the low light cultures were separated, it was observed that the difference between $A_{\mathrm{T} \text { (pred) }}$ and $A_{\mathrm{T} \text { (meas) }}$ slightly decreased with increasing POC concentrations in the high light cultures, ranging between -0.4 and $23.0 \mu \mathrm{mol} \mathrm{kg}{ }^{-1}\left(r^{2}=0.31, n=16\right)$. The average difference between $A_{\mathrm{T} \text { (pred) }}$ and $A_{\mathrm{T} \text { (meas) }}$ was 10.1 $( \pm 6.7) \mu \mathrm{mol} \mathrm{kg}{ }^{-1}$. In the low light cultures, this pattern was reversed and $\Delta A_{\mathrm{T}}$ (pred-meas) showed a minimal increase with an increasing POC concentration. The range of the deviation was -1.9 to $18.6 \mu \mathrm{mol} \mathrm{kg} \mathrm{kg}^{-1}\left(r^{2}=0.10, n=18\right)$. In these low light cultures, the average difference between $A_{\mathrm{T} \text { (pred) }}$ and $A_{\mathrm{T} \text { (meas) }}$ was $6.2( \pm 5.9) \mu \mathrm{mol} \mathrm{kg}{ }^{-1}$.

\subsection{Cell abundance and specific growth rate}

The cell abundance of $P$. globosa in the cultures was kept

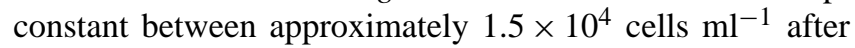
dilution and $5.0 \times 10^{4}$ cells $\mathrm{ml}^{-1}$ before dilution (Fig. 1c and $\mathrm{d}$ ). The cells grew fast at $\mu>0.7 \mathrm{~d}^{-1}$. Average specific growth rates in the HL cultures were significantly higher than in the LL cultures $\left(F_{(1,31)}=5.008, p=0.033\right)$, which is largely due to the high growth rates at low $\mathrm{CO}_{2(\mathrm{aq})}$ concentrations in the HL cultures (Fig. 2). In the HL cultures growth rates were highest at low $\mathrm{CO}_{2(\mathrm{aq})}\left(\mu=1.4 \mathrm{~d}^{-1} \pm 0.1\right)$ while growth rates significantly decreased with increasing $\mathrm{CO}_{2(\mathrm{aq})}$ to $\mu=1.1 \mathrm{~d}^{-1}( \pm 0.1)$ in the high $\mathrm{CO}_{2(\mathrm{aq})}$ treatment ( $\tau=-0.667, p<0.001, n=18$, Fig. 2 ). In the LL cultures no significant trend was observed, growth rates ranged between $\mu=1.0 \mathrm{~d}^{-1}( \pm 0.1)$ in the low $\mathrm{CO}_{2(\mathrm{aq})}$ treatment to $\mu=1.2 \mathrm{~d}^{-1}( \pm 0.1)$ in the high $\mathrm{CO}_{2 \text { (aq) }}$ treatment (Fig. 2).

\subsection{Photosynthetic efficiency and Chlorophyll $a$}

The photosynthetic efficiency $\left(F_{\mathrm{V}} / F_{\mathrm{M}}\right)$ varied between 0.50 and 0.75 throughout the experiment, indicating that the cells

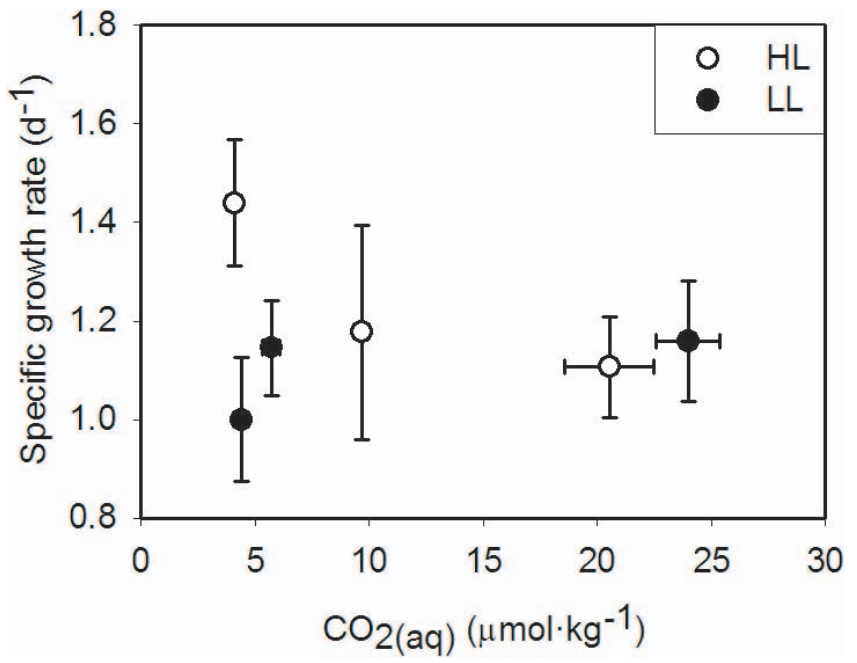

Fig. 2. Growth rates $\left(\mu, \mathrm{d}^{-1}, n=6\right)$ of $P$. globosa during the experiment versus the average $\mathrm{CO}_{2(\mathrm{aq})}$ concentration between dilutions. Open circles denote the HL cultures, closed circles denote LL cultures. Error bars denote the standard deviation.

were healthy and fast growing. The $F_{\mathrm{V}} / F_{\mathrm{M}}$ of the HL cultures ranged between $0.56( \pm 0.03)$ in the low $\mathrm{CO}_{2(\mathrm{aq})}$ treatment and $0.66( \pm 0.02)$ in the high $\mathrm{CO}_{2(\mathrm{aq})}$ treatment (Table 2). The $F_{\mathrm{V}} / F_{\mathrm{M}}$ in the LL cultures was significantly higher than that of the HL cultures $\left(F_{(1,67)}=81.406, p<0.001\right.$, $n=70)$, and ranged between $0.71( \pm 0.02)$ in the low $\mathrm{CO}_{2(\mathrm{aq})}$ treatment and $0.70( \pm 0.02)$ in the high $\mathrm{CO}_{2(\mathrm{aq})}$ treatment (Table 2). The $\left[\mathrm{CO}_{2(\mathrm{aq})}\right]$ also affected the $F_{\mathrm{V}} / F_{\mathrm{M}}$, but only in the HL conditions ( $\tau=0.475, p<0.001, n=34)$.

Chlorophyll $a$ concentrations in the P. globosa cells varied significantly between the two light conditions with approximately $15 \mathrm{pg} \mathrm{cell}^{-1}$ in the HL conditions as compared to higher concentrations, approximately $23 \mathrm{pg} \mathrm{cell}^{-1}$ in the LL conditions $\left(F_{(1,33)}=116.246, p<0.001, n=36\right.$, Table 2). In contrast, the ambient $\mathrm{CO}_{2(\mathrm{aq})}$ concentrations did not affect the chlorophyll $a$ concentration in $P$. globosa cells (HL: $\tau=-0.020, p=0.910, n=18$; LL: $\tau=0.203$, $p=0.240, n=18$, Table 2).

\subsection{Particulate organic carbon and nitrogen}

The POC content of $P$. globosa ranged between 0.9 pmol $\mathrm{C}$ cell $^{-1}$ in the low $\mathrm{CO}_{2(\mathrm{aq})} \mathrm{HL}$ culture and $1.1 \mathrm{pmol} \mathrm{C}$ cell ${ }^{-1}$ in the high $\mathrm{CO}_{2(\mathrm{aq})}$ LL culture (Table 3). The cellular POC concentration was neither influenced by the different $\mathrm{CO}_{2(\mathrm{aq})}$ treatments (HL: $\tau=0.242, p=0.161, n=18$; LL: $\tau=0.324, p=0.070, n=17)$, nor by different light intensities $\left(F_{(1,33)}=0.000, p=1.000, n=36\right.$, Table 3$)$.

The PON content of $P$. globosa ranged between $0.12 \mathrm{pmol}$ $\mathrm{N}$ cell ${ }^{-1}$ in the low $\mathrm{CO}_{2(\mathrm{aq})} \mathrm{HL}$ culture and $0.13 \mathrm{pmol}$ $\mathrm{N}$ cell ${ }^{-1}$ in the high $\mathrm{CO}_{2(\mathrm{aq})}$ LL culture (Table 3). Similar to the POC content of the phytoplankton cells, different $\mathrm{CO}_{2(\mathrm{aq})}$ treatments did also not affect the cellular PON 
Table 2. Photosynthetic efficiency $\left(F_{\mathrm{V}} / F_{\mathrm{M}}\right.$, arbitrary unit a.u., $n=12$ for each treatment, except $n=10$ for intermediate $\left.\mathrm{CO}_{2(\mathrm{aq})} \mathrm{HL}\right)$ and the cellular chlorophyll $a$ contents (pg cell ${ }^{-1}, n=6$ ) of the $P$. globosa cultures in the different experimental treatments. Standard deviations are given between brackets.

\begin{tabular}{lcccccr}
\hline & \multicolumn{2}{c}{$F_{\mathrm{V}} / F_{\mathrm{M}}$ (a.u.) } & & \multicolumn{2}{c}{ Chlorophyll $a\left(\mathrm{pg} \mathrm{cell}^{-1}\right)$} \\
\cline { 2 - 3 } & \multicolumn{2}{c}{ High light } & Low light & & High light & Low light \\
\hline Low $\mathrm{CO}_{2(\mathrm{aq})}$ & $0.56( \pm 0.03)$ & $0.71( \pm 0.02)$ & & $0.16( \pm 0.01)$ & $0.22( \pm 0.02)$ \\
Intermediate $\mathrm{CO}_{2(\mathrm{aq})}$ & $0.65( \pm 0.02)$ & $0.70( \pm 0.03)$ & & $0.15( \pm 0.01)$ & $0.23( \pm 0.03)$ \\
High $\mathrm{CO}_{2(\mathrm{aq})}$ & $0.66( \pm 0.02)$ & $0.70( \pm 0.02)$ & & $0.16( \pm 0.02)$ & $0.24( \pm 0.03)$ \\
\hline
\end{tabular}

Table 3. Particulate organic carbon (POC) and nitrogen $(\mathrm{PON})$ contents per cell (pmol cell ${ }^{-1}$ ), and the ratio values of POC to PON (POC:PON) and POC to chlorophyll $a$ (POC: $\mathrm{Chl} a$ ) in the different light and carbon treatments. Standard deviations are given between brackets, $n=6$ for all treatments.

\begin{tabular}{lrrrr}
\hline & POC & PON & POC:PON & POC:Chl $a$ \\
\hline High Light & & & & \\
\hline Low $\mathrm{CO}_{2(\mathrm{aq})}$ & $0.9( \pm 0.06)$ & $0.12( \pm 0.01)$ & $7.7( \pm 0.8)$ & $69.1( \pm 4.4)$ \\
Intermediate $\mathrm{CO}_{2(\mathrm{aq})}$ & $1.0( \pm 0.11)$ & $0.13( \pm 0.02)$ & $8.2( \pm 0.7)$ & $82.4( \pm 11.4)$ \\
High $\mathrm{CO}_{2(\mathrm{aq})}$ & $1.0( \pm 0.41)$ & $0.12( \pm 0.05)$ & $8.9( \pm 1.6)$ & $76.2( \pm 24.8)$ \\
\hline Low Light & & & & \\
\hline Low $\mathrm{CO}_{2(\mathrm{aq})}$ & $1.0( \pm 0.13)$ & $0.12( \pm 0.02)$ & $8.2( \pm 0.7)$ & $53.6( \pm 8.8)$ \\
Intermediate $\mathrm{CO}_{2(\mathrm{aq})}$ & $1.0( \pm 0.06)$ & $0.13( \pm 0.02)$ & $8.0( \pm 0.7)$ & $54.0( \pm 7.5)$ \\
High $\mathrm{CO}_{2(\mathrm{aq})}$ & $1.1( \pm 0.11)$ & $0.13( \pm 0.02)$ & $8.4( \pm 1.0)$ & $56.1( \pm 8.4)$ \\
\hline
\end{tabular}

content (HL: $\tau=0.216, p=0.211, n=18$; LL: $\tau=0.190$, $p=0.272, n=18)$, nor did the different light conditions $\left(F_{(1,33)}=0.000, p=1.000, n=36\right.$, Table 3$)$.

With little effect of both light intensities and the $\mathrm{CO}_{2(\mathrm{aq})}$ concentration on the POC and PON concentration of the cells, the POC:PON ratio also remained virtually constant, ranging from $7.7( \pm 0.8)$ to $8.9( \pm 1.6)$ in the high light cultures and between $8.0( \pm 0.7)$ and $8.4( \pm 1.0)$ in the low light cultures (Table 3 ).

The ratio values of organic carbon (POC) to chlorophyll $a$ (POC:Chl $a$ ) on the other hand, varied between $53.6( \pm 8.8)$ pg C pg Chl $a^{-1}$ in the low $\left[\mathrm{CO}_{2(\mathrm{aq})}\right] \mathrm{LL}$ treatment to 82.4 $( \pm 11.4)$ pg C pg Chl $a^{-1}$ in the intermediate $\left[\mathrm{CO}_{2(\mathrm{aq})}\right] \mathrm{HL}$ treatment (Table 3).

There was no significant effect of the $\left[\mathrm{CO}_{2(\mathrm{aq})}\right]$ on the POC:Chl $a$ ratio for both the HL $(\tau=0.229, p=0.185, n=$ 18 ) and the LL cultures ( $\tau=0.124, p=0.472, n=18)$. In the high light cultures POC:Chl $a$ was significantly higher compared to the low light cultures, due to lower Chl $a$ concentrations per cell in the HL cultures $\left(F_{(1,33)}=25.309, p<0.001\right.$, $n=36$, Tables 2 and 3 ).

\subsection{Nutrients}

The removal of the dissolved nutrients between two consecutive dilutions was on average $0.15( \pm 0.07) \mu \mathrm{mol} 1^{-1}$ for phos- phate and $2.34( \pm 0.72) \mu \mathrm{mol} \mathrm{l}^{-1}$ for nitrate (Supplement, Tables S4 and S5). The average removal between dilutions was therefore approximately $4 \%$ of the initial nutrient stocks in the vessels. Nutrient removal was never more than $10 \%$ of the total nutrient stocks, and therefore, never considered to result in nutrient limitation.

The rates of uptakes of phosphate by $P$. globosa were not significantly influenced by the different light treatments $\left(F_{(1,30)}=0.036, p=0.851, n=32\right)$ and ranged between 5.7 and 9.2 fmol cell ${ }^{-1} \mathrm{~d}^{-1}$ in the low $\mathrm{CO}_{2(\mathrm{aq})} \mathrm{LL}$ culture and the intermediate $\mathrm{CO}_{2(\mathrm{aq})} \mathrm{HL}$ culture, respectively (Table 4$)$. Both in the HL $(\tau=0.451, p=0.025, n=14)$, and in the LL treatments ( $\tau=0.412, p=0.017, n=18)$ the increasing $\left[\mathrm{CO}_{2(\mathrm{aq})}\right]$ stimulated phosphate uptake rates, but the variability in these measurements was large.

The rates of nitrate uptake showed similar responses to light as the rates of phosphate uptake (Table 4). There was no significant effect of the different light treatments on nitrate uptake rates $\left(F_{(1,30)}=0.908, p=0.348, n=32\right)$. In the HL cultures, the $\left[\mathrm{CO}_{2(\mathrm{aq})}\right]$ did not have a significant effects on nitrate uptake rates $(\tau=0.231, p=0.250, n=14)$. In the LL cultures on the other hand, nitrate uptake rates significantly increased with increasing $\left[\mathrm{CO}_{2(\mathrm{aq})}\right](\tau=0.595$, $p=0.001, n=18)$, ranging between $96.2 \mathrm{fmol} \mathrm{cell}^{-1} \mathrm{~d}^{-1}$ in 
Table 4. Rates of nutrient uptake (fmol cell ${ }^{-1} \mathrm{~d}^{-1}$ ) in the culture vessels and the nitrogen to phosphorus uptake ratios (N:P). Standard deviations are given between brackets, $n=6$ for each treatment, except for high light, low and intermediate $\mathrm{CO}_{2(\mathrm{aq})}$ where $n=5$.

\begin{tabular}{|c|c|c|c|c|c|c|}
\hline & \multicolumn{2}{|c|}{$\mathrm{NO}_{3}^{-}\left(\right.$fmol cell $\left.{ }^{-1} \mathrm{~d}^{-1}\right)$} & \multicolumn{2}{|c|}{$\mathrm{PO}_{4}^{3-}\left(\mathrm{fmol}\right.$ cell $\left.{ }^{-1} \mathrm{~d}^{-1}\right)$} & \multicolumn{2}{|c|}{$\mathrm{N}: \mathrm{P}$} \\
\hline & High light & Low light & High light & Low light & High light & Low light \\
\hline Low $\mathrm{CO}_{2(\mathrm{aq})}$ & $118.4( \pm 22.6)$ & $96.2( \pm 17.1)$ & $6.9( \pm 1.5)$ & $5.7( \pm 1.0)$ & $17.4( \pm 2.9)$ & $17.1( \pm 3.5)$ \\
\hline Intermediate $\mathrm{CO}_{2(\mathrm{aq})}$ & $133.5( \pm 29.8)$ & $115.1( \pm 18.6)$ & $9.2( \pm 3.5)$ & $7.9( \pm 7.5)$ & $15.7( \pm 4.6)$ & $21.6( \pm 10.6)$ \\
\hline $\mathrm{High} \mathrm{CO}_{2(\mathrm{aq})}$ & $128.4( \pm 18.5)$ & $142.3( \pm 22.7)$ & $8.8( \pm 2.0)$ & $9.0( \pm 3.2)$ & $15.1( \pm 3.2)$ & $17.0( \pm 5.1)$ \\
\hline
\end{tabular}

the low $\mathrm{CO}_{2(\mathrm{aq})}$ culture to $142.3 \mathrm{fmol}$ cell ${ }^{-1} \mathrm{~d}^{-1}$ in the high $\mathrm{CO}_{2(\mathrm{aq})}$ culture.

The ratio of uptake of nitrate to phosphate $(\mathrm{N}: \mathrm{P})$, hence cellular N:P content ranged between 17.0 and 21.6 in the low light cultures and between 15.1 and 17.4 in the HL cultures (Table 4). There was no significant effect of the two different light intensities on the N:P ratio $\left(F_{(1,30)}=1.062\right.$, $p=0.311, n=32)$. Furthermore, $\left[\mathrm{CO}_{2(\mathrm{aq})}\right]$ did not significantly affect the N:P ratio either (HL: $\tau=-0.385, p=0.055$, $n=14$; LL: $\tau=0.098, p=0.570, n=18$ ).

\section{Discussion}

The increasing atmospheric concentrations of carbon dioxide due to anthropogenic $\mathrm{CO}_{2}$ emissions lead to changes the inorganic carbon chemistry of seawater. These changes may affect marine phytoplankton and here we report on the findings of carbon perturbation experiments with Phaeocystis globosa. We combined three different inorganic carbon treatments with two different light intensities on P. globosa in our experiments. In practice, even with constant aeration it proved to be very difficult to reach the desired concentration of inorganic carbon in the culture medium. This was mainly due to the photosynthesis by the phytoplankton, which could be concluded from the larger variability of the DIC concentrations (approx. $1 \%$ ) compared to the $A_{\mathrm{T}}$ (approx. $0.1 \%$ ). Due to the daily dilution approach, this variability still was minor and resulted in stable inorganic carbon chemistry in the cultures, with a maximum variability in the $\mathrm{CO}_{2(\mathrm{aq})}$ concentrations of only $10 \%$ within each culture. A difference in the $\left[\mathrm{CO}_{2(\mathrm{aq})}\right]$ was found between the intermediate $\mathrm{CO}_{2(\mathrm{aq})}$ $\mathrm{HL}$ and LL culture, with the $\left[\mathrm{CO}_{2(\mathrm{aq})}\right]$ of the LL culture being lower than that of the HL culture. This was due to technical problems rather than to biological activity, since the $\left[\mathrm{CO}_{2(\mathrm{aq})}\right]$ in the supply vessel was also significantly lower (Table 1). However, because regular samples for the determination of the carbonate system were taken, this could be accounted for in the analysis of the results.

In their study, Kim et al. (2006) reported significant effects of particulate organic carbon concentrations on $A_{\mathrm{T}}$ measurements. Increasing [POC] led to an increased discrepancy between the measured $A_{\mathrm{T}}$ of filtered and unfiltered phyto- plankton cultures. The slight discrepancy between the measured and the predicted $A_{\mathrm{T}}$ in our study was within the measurement accuracy and the results showed that there was no systematic effect of the POC concentration and changes therein on the measured $A_{\mathrm{T}}$. At most we found a weak trend, but this trend was opposite to the results reported by Kim et al. (2006). This difference in response is likely due to the $[\mathrm{POC}]$ in the different studies. Particulate organic carbon concentrations in our study ranged between 12.3 and $55.0 \mu \mathrm{mol} 1^{-1}$, with an average of $38.1 \mu \mathrm{mol} 1^{-1}$, while the [POC] in the study by Kim et al. (2006) ranged between approximately 200 and $1100 \mu \mathrm{mol} \mathrm{I}^{-1}$. This shows that it is very important to maintain low cell abundance in carbon perturbation experiments in order to obtain accurate data.

The results of our experiments showed that $P$. globosa is a highly adaptive species which was able to maintain high growth rates in a large range of environmental conditions. Despite the substantial differences in $\mathrm{CO}_{2(\mathrm{aq})}$ concentrations and the two different light treatments (saturating and suboptimal), cells in all cultures were growing fast, dividing more than once per day. The growth rates in the low light cultures were not influenced by the different $\mathrm{CO}_{2(\mathrm{aq})}$ conditions, which is comparable to the results of Wang et al. (2010a), who also did not find an increased growth rate of solitary cells of P. globosa in their experiments. However, their results also showed that the growth rate of colonial cells was significantly increased in the high $\mathrm{CO}_{2}$ cultures. This demonstrates that it is necessary to study the different morphotypes of $P$. globosa in more detail, since the cells in high light cultures of our experiments grew comparatively faster as compared to the low light cultures, and here the growth rate was negatively influenced by higher $\left[\mathrm{CO}_{2(\mathrm{aq})}\right]$. The results from the high light cultures corroborate the observations by Chen and Gao (2011), who also found decreasing growth rates with increasing $\left[\mathrm{CO}_{2}\right]$ in high light conditions. In contrast, under low light conditions growth rates of $P$. globosa increased with increasing $\mathrm{CO}_{2}$ in their study. Because of the differences in the research question between the study of Chen and Gao (2011), who were interested in natural light regimes, and our study with stable light regimes, it is difficult to compare the two. Irrespective of this, our results, and the results of Wang et al. (2010a) suggest that the effects of $\mathrm{CO}_{2}$ 
on growth rates of solitary P. globosa cells are consistent among different strains of this species.

Although $F_{\mathrm{V}} / F_{\mathrm{M}}$ is generally considered a good measure for cell fitness, the results of the growth rates and $F_{\mathrm{V}} / F_{\mathrm{M}}$ measurements did contradict each other. Increasing $\mathrm{CO}_{2(\mathrm{aq})}$ concentrations lead to a minor, but significant increase in the photosynthetic efficiency in the high light cultures, while growth rates decreased. These results contradict the results of Wang et al. (2010a), who showed a lower $F_{\mathrm{V}} / F_{\mathrm{M}}$ at low $\mathrm{CO}_{2}$. In their study, $F_{\mathrm{V}} / F_{\mathrm{M}}$ in the batch cultures decreased during the experiment, and the difference between the two treatments only became visible after the number of colonial cells in the cultures dropped significantly. This suggests that this difference in $F_{\mathrm{V}} / F_{\mathrm{M}}$ is most likely not entirely due to the different $\mathrm{CO}_{2}$ concentrations, but more likely related to the abundance of colonial and solitary cells and perhaps nutrient and light limitation. Because the environmental conditions in batch cultures are strongly influenced by growth, we used a semi-continuous set-up, resulting in a stable $F_{\mathrm{V}} / F_{\mathrm{M}}$ throughout the experiment. Similarly, cellular POC and PON concentrations were relatively stable throughout our experiments, but variability in cellular POC and PON content increased with increasing $\left[\mathrm{CO}_{2(\mathrm{aq})}\right]$. Neither of the two parameters, nor the POC:PON ratios were affected by the different $\mathrm{CO}_{2(\mathrm{aq})}$ treatments. This is in contrast to the findings by Wang et al. (2010a). While Wang et al. (2010a) studied both solitary and colonial cells; we only examined the effects of variations in light and inorganic carbon on solitary cells. The different results suggest that the elevated POC contents of the cells might be more likely present in the mucus layer of the colonial cells than in the solitary cells (see also Schoemann et al., 2005 and Rousseau et al., 2007, and references therein). The ratios of POC:PON that were measured in the present study, ranging between 7.7 and 8.9, were higher than the ratio's that have been previously measured in cultures or field samples of solitary P. globosa cells, which range between 4.0 and 6.0, but comparable to colonial stoichiometry, ranging between 6.5 and 9.7, the latter which was measured in P-deficient conditions (Schoemann et al., 2005 and references therein).

Furthermore, cellular PON production rates matched nitrate uptake rates, suggesting that indeed all the $\mathrm{NO}_{3}^{-}$removed from the culture medium was assimilated and converted in structural biomass by $P$. globosa. Based on this observation the assumption was made that the same was true for phosphate and the ratios of $\mathrm{C}: \mathrm{P}$ (carbon:phosphorus) were determined (data not shown). The $\mathrm{C}: \mathrm{P}$ ratios ranged between 126 and 188, with the highest ratios in the low light cultures. These ratios are comparable to the large range of $\mathrm{C}: \mathrm{P}$ ratios found for colonial cells by Jahnke (1989).

Since light is an important trigger for P. globosa blooms in the Dutch coastal North Sea (Peperzak et al., 1998), two different light conditions were incorporated in our experimental setup. Light saturation for optimal cell division of $P$. globosa was reported to be $180 \mu \mathrm{mol}$ photons $\mathrm{m}^{-2} \mathrm{~s}^{-1}$ (Jahnke, 1989;
Meyer et al., 2000), which is slightly lower that the saturating light conditions used in our experiments $(240 \mu \mathrm{mol}$ photons $\left.\mathrm{m}^{-2} \mathrm{~s}^{-1}\right)$. The results of our experiments showed only a moderate effect of low light on the photosynthetic efficiency $\left(F_{\mathrm{V}} / F_{\mathrm{M}}\right.$ in LL cultures was $10-20 \%$ higher, compared to the high light cultures), but the cells responded by increasing the chlorophyll $a$ concentration by as much as $50 \%$. It has been shown that other Phaeocystis species are also affected by different light intensities and that for example $P$. antarctica is susceptible to photo-inhibition. This species needs a dark period, provided by deep mixing, for efficient photosynthesis (Mills et al., 2010; Arrigo et al., 1999). The differences in $F_{\mathrm{V}} / F_{\mathrm{M}}$ in $P$. globosa due to the different light conditions in our study are comparable to findings of Mills et al. (2010) and van Leeuwe and Stefels (2007), who found a decrease of $F_{\mathrm{V}} / F_{\mathrm{M}}$ in $P$. antarctica with increasing light conditions. Although in the study by Mills et al. (2010) no general effect of the irradiance level on chlorophyll concentrations was found. One of the tested strains (\#1374) did show an increase in the POC:Chl $a$ ratio with increasing light, which is similar to our results for $P$. globosa, although their ratios for $P$. antarctica were much higher than those of $P$. globosa in our study. Because the second strain of $P$. antarctica in the study by Mills et al. (2010) did not show an increasing POC:Chl $a$ ratio, we might conclude that this is a strain specific response. The increased POC:Chl $a$ ratio in our experiments was comparable to ratios measured for an Antarctic Phaeocystis sp. at $110 \mu \mathrm{mol}$ photons $\mathrm{m}^{-2} \mathrm{~s}^{-1}$ (Stefels and Van Leeuwe, 1998). Light conditions also have shown to affect $P$. pouchetii. A study by Hegarty and Villareal (1998) has demonstrated that $P$. pouchetii reached maximum growth rates at low irradiance levels, while our results showed that $P$. globosa growth rates decreased in low light conditions, supporting the conclusion of Hegarty and Villareal (1998) that the two species differ in the relative growth potential at different light conditions.

The results of our study have shown that the effects of light on $P$. globosa are much less pronounced as compared to the other species. This could be explained by the environmental conditions in which these different species live. While $P$. antarctica and $P$. pouchetii are both cold water (polar) species, and therefore more subjected to periods of low light and darkness, $P$. globosa is a species that occurs in warmer, temperate waters, with smaller differences in light availability. Therefore, $P$. globosa is less likely to become photo-inhibited at the high light conditions in our experiments. Furthermore, our experiments have shown that in high light conditions, for example caused by increased stratification, growth rates are decreasing with increasing $\left[\mathrm{CO}_{2(\mathrm{aq})}\right]$. This suggests that the primary production by $P$. globosa will decrease in the future ocean. The increased phosphate uptake rates at high $\left[\mathrm{CO}_{2(\mathrm{aq})}\right]$ suggests that the cells require more nutrients at high $\left[\mathrm{CO}_{2(\mathrm{aq})}\right]$. Because the Dutch coastal North Sea and Wadden Sea are phosphate controlled at present (Philippart et al., 2000; P. Ruardij, NIOZ, Texel, personal communication, 2011), the ability of P. globosa to 
outcompete other phytoplankton species in these and other waters might decrease in the future. Because P. globosa is a strong DMS producer, a decrease in $P$. globosa presence would also cause a decrease in DMS production, which could lead to a decrease in the strength of the negative feedback to global warming, hence increasing temperatures further. The increasing temperature and the increasing atmospheric $\mathrm{CO}_{2}$ concentrations will most likely amplify the effects of either one of these stress factors and can significantly change the primary production, and therefore the carbon sequestration by $P$. globosa.

\section{Supplementary material related to this article is available online at: http://www.biogeosciences.net/9/ 1885/2012/bg-9-1885-2012-supplement.pdf.}

Acknowledgements. For the analysis of the nutrient samples we thank the nutrient laboratory of the Royal Netherlands Institute for Sea Research. Furthermore, we thank Sharyn Crayford for the analysis of the particulate organic nitrogen and carbon samples, and Marcel Veldhuis and the reviewers for reading and commenting on the manuscript. This work was funded by the Darwin Center for Biogeology, 5th call, under project number 2061. This work is also a contribution to the "European Project on Ocean Acidification" (EPOCA) which received funding from the European Community's Seventh Framework Programme (FP7/2007-2013) under grant agreement no. 211384.

Edited by: G. Herndl

\section{References}

Arrigo, K. R., Robinson, D. H., Worthen, D. L., Dunbar, R. B., DiTullio, G. R., VanWoert, M., and Lizotte, M. P.: Phytoplankton community structure and the drawdown of nutrients and $\mathrm{CO}_{2}$ in the Southern Ocean, Science, 283, 365-367, 1999.

Brewer, P. G. and Goldman, J. C.: Alkalinity Changes Generated by Phytoplankton Growth, Limnol. Oceanogr., 21, 108-117, 1976.

Brussaard, C. P. D., Kuipers, B., and Veldhuis, M. J. W.: A mesocosm study of Phaeocystis globosa population dynamics -1 . Regulatory role of viruses in bloom, Harmful Algae, 4, 859-874, 2005.

Charlson, R. J., Lovelock, J. E., Andreae, M. O., and Warren, S. G.: Oceanic phytoplankton, atmospheric sulphur, cloud albedo and climate, Nature, 326, 655-661, 1987.

Chen, S. and Gao, K. S.: Solar ultraviolet radiation and $\mathrm{CO}_{2}-$ induced ocean acidification interacts to influence the photosynthetic performance of the red tide alga Phaeocystis globosa (Prymnesiophyceae), Hydrobiologia, 675, 105-117, 2011.

Chen, Y.-Q., Wang, N., Zhang, P., and Que, L.-H.: Molecular evidence identifies bloom forming Phaeocystis (Prymnesiophytha) from coastal waters of southeast China as Phaeocystis globosa, Biochem. Syst. Ecol., 30, 15-22, 2002.

Clarke, A. D., Davis, D., Kapustin, V. N., Eisele, F., Chen, G., Paluch, I., Lenschow, D., Bandy, A. R., Thornton, D., Moore, K., Mauldin, L., Tanner, D., Litchy, M., Carroll, M. A., Collins,
J., and Albercook, G.: Particle nucleation in the tropical boundary layer and its coupling to marine sulfur sources, Science, 282, 89-92, 1998.

Dickson, A. G.: Standard potential of the reaction $\mathrm{AgCl}_{(\mathrm{S})}+{ }^{1} /{ }_{2} \mathrm{H}_{2(\mathrm{G})}=\mathrm{Ag}_{(\mathrm{S})}+\mathrm{HCl}_{(\mathrm{Aq})}$ and the standard acidity constant of the ion $\mathrm{HSO}_{4}^{-}$in synthetic sea water from 273.15 K to 318.15 K, J. Chem. Thermodyn., 22, 113-127, 1990a.

Dickson, A. G.: Thermodynamics of the dissociation of boric acid in synthetic seawater from $273.15 \mathrm{~K}$ to $318.15 \mathrm{~K}$, Deep-Sea Res., 37, 755-766, 1990b.

Dickson, A. G. and Goyet, C.: Handbook of methods for the analysis of the various parameters of the carbon dioxide system in sea water, edited by: Dickson, A. G. and Goyet, C., 187 pp., 1994.

Dickson, A. G. and Millero, F. J.: A comparison of the equilibrium constants for the dissociation of carbonic acid in seawater media, Deep-Sea Res., 34, 1733-1743, 1987.

Dickson, A. G., Sabine, C. L., and Christian, J. R.: Guide to the best practices for ocean $\mathrm{CO}_{2}$ measurements. Pices special publication 3, North Pacific Marine Organization, Sidney, Canada, 191 pp., 2007.

Engel, A., Zondervan, I., Aerts, K., Beaufort, L., Benthien, A., Chou, L., Delille, B., Gattuso, J. P., Harlay, J., Heemann, C., Hoffmann, L., Jacquet, S., Nejstgaard, J., Pizay, M. D., RochelleNewall, E., Schneider, U., Terbrueggen, A., and Riebesell, U.: Testing the direct effect of $\mathrm{CO}_{2}$ concentration on a bloom of the coccolithophorid Emiliania huxleyi in mesocosm experiments, Limnol. Oceanogr., 50, 493-507, 2005.

Field, A.: Discovering Statistics using SPSS, SAGE Publications Ltd, London, 816 pp., 2007.

Fu, F.-X., Place, A. R., Garcia, N. S., and Hutchins, D. A.: $\mathrm{CO}_{2}$ and phosphate availability control the toxicity of the harmful bloom dinoflagellate Karlodinium veneficum, Aquat. Microb. Ecol., 59, $55-65,2010$.

Goldman, J. C. and Brewer, P. G.: Effect of nitrogen-source and growth-rate on phytoplankton-mediated changes in alkalinity, Limnol. Oceanogr., 25, 352-357, 1980.

Grasshoff, K., Ehrhardt, M., and Kremling, K.: Methods of seawater analysis, Wiley VCH, Weinheim, 447 pp., 1983.

Hegarty, S. G. and Villareal, T. A.: Effects of light level and $\mathrm{N}: \mathrm{P}$ supply ratio on the competetion between Phaeocystis cf. pouchetii (Hariot) Lagerheim (Prymnesiophyceae) and five diatom species, J. Exp. Mar. Biol. Ecol., 226, 241-258, 1998.

Holm-Hansen, O., Lorenzen, C. J., Homes, R. W., and Strickland, J. D. H.: Fluorometric determination of chlorophyll, J. Cons. Int. Explor. Mer., 30, 3-15, 1965.

Hoogstraten, A., Timmermans, K. R.. and de Baar, H. J. W.: Morphological and physiological effects in Proboscia alata (Bacillariophyceae) grown under different light and $\mathrm{CO}_{2}$ conditions of the modern Southern Ocean, J. Phycol., in press, 48, doi:10.1111/j.1529-8817.2012.01148.x, 2012.

Iglesias-Rodriguez, M. D., Halloran, P. R., Rickaby, R. E. M., Hall, I. R., Colmenero-Hidalgo, E., Gittins, J. R., Green, D. R. H., Tyrrell, T., Gibbs, S. J., von Dassow, P., Rehm, E., Armbrust, E. V., and Boessenkool, K. P.: Phytoplankton calcification in a high- $\mathrm{CO}_{2}$ world, Science, 320, 336-340, 2008.

Jacobsen, A., Larsen, A., Martinez-Martinez, J., Verity, P. G., and Frischer, M. E.: Susceptibility of colonies and colonial cells of Phaeocystis pouchetii (Haptophyta) to viral infection, Aquat. Microb. Ecol., 48, 105-112, doi:10.3354/ame048105, 2007. 
Jahnke, J.: The light and temperature-dependence of growth-rate and elemental composition of Phaeocystis-globosa Scherffel and Phaeocystis-pouchetii (Har) Lagerh in Batch Cultures, Neth. J. Sea Res., 23, 15-21, 1989.

Kim, H. C., Lee, K., and Choi, W. Y.: Contribution of phytoplankton and bacterial cells to the measured alkalinity of seawater, Limnol. Oceanogr., 51, 331-338, 2006.

Lewis, E. and Wallace, D. W. R.: Program developed for $\mathrm{CO}_{2}$ system calculations. Carbon Dioxide Information Analysis Center, Oak Ridge National Laboratory, US Department of Energy, Oak Ridge, Tennessee, USA, 1998.

Lu, D. and Huang, W.: Phaeocystis bloom in southeast China coastal waters 1997, Harmful algae news, 19, 9 pp., 1999.

Mari, X., Rassoulzadegan, F., Brussaard, C. P. D., and Wassmann, P.: Dynamics of transparent exopolymeric particles (TEP) production by Phaeocystis globosa under N- or P-limitation: a controlling factor of the retention/export balance, Harmful Algae, 4, 895-914, 2005.

Meehl, G. A., Stocker, T. F., Collins, W. D., Friedlingstein, P., Gaye, A. T., Gregory, J. M., Kitoh, A., Knutti, R., Murphy, J. M., Noda, A., Raper, D. C. B., Watterson, I. G., Weaver, A. J., and Zhao, Z.-C. I. E.: Global climate projections, in: Climate Change 2007: The physical science basis. Contribution of Working Group I to the Fourth Assesment Report of the Intergovernmental Panel on Climate Change, edited by: Solomon, S., Qin, D., Manning, M., Chen, Z., Marquis, M., Averyt, K. B., Tignor, M., and Miller, H. L., Cambridge, United Kingdom and New York, NY, USA, Cambridge, 747-845, 2007.

Mehrbach, C., Culberson, C. H., Hawley, J. E., and Pytkowicz, R. M.: Measurement of the apparent dissociation constants of carbonic acid in seawater at atmospheric pressure, Limnol. Oceanogr., 18, 897-907, 1973.

Meyer, A. A., Tackx, M., and Daro, N.: Xanthophyll cycling in Phaeocystis globosa and Thalassiosira sp.: a possible mechanism for species succession, J. Sea Res., 43, 373-384, 2000.

Millero, F. J.: The carbonate system, in: Chemical Oceanography, edited by: Millero, F. J., 2nd Edn., CRC Marine Science Series, CRC Press LLC, Boca Raton, Fl, USA, 237-279, ISBN-0-84938423-0, 1996.

Mills, M. M., Kropuenske, L. R., Van Dijken, G. L., Alderkamp, A.-C., Berg, G. M., Robinson, D. H., Welschmeyer, N. A., and Arrigo, K. R.: Photophysiology in two Southern Ocean phytoplankton taxa: photosynthesis of Phaeocystis antarctica (Prymnesiophyceae) and Fragilariopsis cylindrus (Bacillariophyceae) under simulated mixed layer irradiance, J. Phycol., 46, 11141127, 2010.

Peperzak, L.: Climate change and harmful algal blooms in the North Sea, Acta Oecol., 24, S139-S144, 2003.

Peperzak, L. and Poelman, M.: Mass mussel mortality in The Netherlands after a bloom of Phaeocystis globosa (prymnesiophyceae), J. Sea Res., 60, 220-222, 2008.

Peperzak, L., Colijn, F., Gieskes, W. W. C., and Peeters, J. C. H.: Development of the diatom-Phaeocystis spring bloom in the Dutch coastal zone of the North Sea: the silicon depletion versus the daily irradiance threshold hypothesis, J. Plankton Res., 20, 517-537, 1998.

Philippart, C. J. M., Cadeé, G. C., van Raaphorst, W., and Riegman, R.: Long-term phytoplankton-nutrient interactions in a shallow coastal sea: Algal community structure, nutrient budgets, and denitrification potential, Limnol. Oceanogr., 45, 131-144, 2000.

Riebesell, U., Fabry, V. J., Hansson, L., and Gattuso, J.-P.: Guide to best practices for ocean acidification research and data reporting, Publications Office of the European Union, Luxembourg, 260 pp., 2010.

Riegman, R. and van Boekel, W.: The ecophysiology of Phaeocystis globosa: A review, J. Sea Res., 35, 235-242, 1996.

Rousseau, V., Vaulot, D., Casotti, R., Cariou, V., Lenz, J., Gunkel, J., and Baumann, M.: The life-cycle of Phaeocystis (Prymnesiophyceae) - Evidence and hypotheses, J. Marine Syst., 5, 23-39, 1994.

Rousseau, V., Chretiennot-Dinet, M. J., Jacobsen, A., Verity, P., and Whipple, S.: The life cycle of Phaeocystis: state of knowledge and presumptive role in ecology, Biogeochemistry, 83, 29-47, 2007.

Sabine, C. L., Feely, R. A., Gruber, N., Key, R. M., Lee, K., Bullister, J. L., Wanninkhof, R., Wong, C. S., Wallace, D. W. R., Tilbrook, B., Millero, F. J., Peng, T. H., Kozyr, A., Ono, T., and Rios, A. F.: The oceanic sink for anthropogenic $\mathrm{CO}_{2}$, Science, 305, 367-371, 2004.

Schoemann, V., Becquevort, S., Stefels, J., Rousseau, W., and Lancelot, C.: Phaeocystis blooms in the global ocean and their controlling mechanisms: a review, J. Sea Res., 53, 43-66, 2005.

Shen, P. D., Qi, Y., Wang, Y., and Huang, L.: Phaeocystis globosa Scherffel, a harmful microalga, and its production of dimethylsulfoniopropionate, Chin. J. Oceanol. Limn., 29, 869873, doi:10.1007/s00343-011-0515-7, 2011.

Stefels, J.: Physiological aspects of the production and conversion of DMSP in marine algae and higher plants, J. Sea Res., 43, 183197, 2000.

Stefels, J. and Van Leeuwe, M. A.: Effects of iron and light stress on the biochemical composition of Antarctic Phaeocystis sp. (Prymnesiophyceae), I. Intracellular DMSP concentrations, J. Phycol., 34, 486-495, 1998.

Stefels, J., Dijkhuizen, L., and Gieskes, W. W. C.: Dmsp-lyase activity in a spring phytoplankton bloom off the dutch coast, related to Phaeocystis sp abundance, Mar. Ecol. Prog. Ser., 123, 235-243, 1995.

Sun, J., Hutchins, D. A., Feng, Y., Seubert, E. L., Caron, D. A., and Fua, F.-X.: Effects of changing $p \mathrm{CO}_{2}$ and phosphate availability on domoic acid production and physiology of the marine harmful bloom diatom Pseudo-nitzschia multiseries, Limnol. Oceanogr., 56, 829-840, 2011.

Tang, K. W.: Grazing and colony size development in Phaeocystis globosa (Prymnesiophyceae): the role of a chemical signal, J. Plankton Res., 25, 831-842, 2003.

Tatters, A. O., Fu, F.-X., and Hutchins, D. A.: High $\mathrm{CO}_{2}$ and silicate limitaiton synergistically increase the toxicity of Pseudonitzschia fraudulenta, PLoS ONE, 7, e32116, 1-7, 2012.

Timmermans, K. R., Davey, M. S., van der Wagt, B., Snoek, J., Geider, R. J., Veldhuis, M. J. W., Gerringa, L. J. A., and de Baar, H. J. W.: Co-limitation by iron and light of Chaetoceros brevis, $C$. dichaeta and C. calcitrans (Bacillariophyceae), Mar. Ecol. Prog. Ser., 217, 287-297, 2001.

van Leeuwe, M. A. and Stefels, J.: Photosynthetic responses in Phaeocystis antarctica towards varying light and iron conditions, Biogeochemistry, 83, 61-70, 2007.

Verardo, D. J., Froelich, P. N., and McIntyre, A.: Determination of organic carbon and nitrogen in marine sediments using the Carlo- 
Erba-Na-1500 Analyzer, Deep-Sea Res., 37, 157-165, 1990.

Wang, Y., Smith Jr., W. O., Wang, X., and Li, S.: Subtle biological responses to increased $\mathrm{CO}_{2}$ concentrations by Phaeocystis globosa Scherffel, a harmful algal bloom species, Geophys. Res. Lett., 37, L09604, doi:10.1029/2010g1042666, 2010a.

Wang, X., Tang, K. W., Wang, Y., and Smith Jr., W. O.: Temperature effects on growth, colony development and carbon partitioning in three Phaeocystis species, Aquat. Biol., 9, 239-249, doi:10.3354/ab00256, 2010b.
Weiss, R. F.: Carbon dioxide in water and Seawater: the solubility of a non-ideal gas, Mar. Chem., 2, 203-215, 1974.

Whipple, S. J., Patten, B. C., and Verity, P. G.: Life cycle of the marine alga Phaeocystis: A conceptual model to summarize literature and guide research, J. Mar. Syst., 57, 83-110, 2005. 